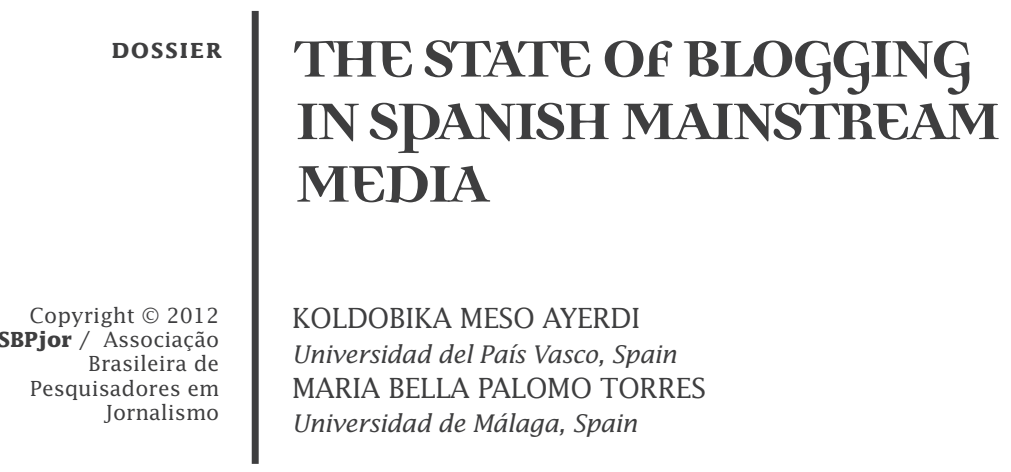

\begin{abstract}
In this paper we aim to draw a picture of what is happening in Spanish mainstream cybermedia from the point of view of new ways of participation and, more concretely, we analyze remarkable weblogs signed by journalists and/or guests, in order to determine the author's profile. A survey answered by 50 per cent of these bloggers let us know why the use of weblogs represents the key to media success in the online sphere. During 2008, we analyzed several national (Abc.es, Elmundo.es, Elpais.es) and regional (Elcorreodigital.com, Lavanguardia.es) internet newspapers, and we underline the special case of Vocento, one of the main multimedia group in Spain. Our results show that offering outstanding weblogs is a good strategy against crisis: media obtain a significant amount of online content automatically and with no investment needed. This helps to increase the website traffic, to lenghten the time spent by visitors; and to obtain a better place in web search engines.
\end{abstract}

Keywords: Internet. Cybermedia. Weblog. Journalist. Spain.

\title{
O ESTADO DOS BLOGS NA MÍDIA ESPANHOLA
}

RESUMO - Neste artigo pretendemos fazer um mapeamento sobre o estado em que se encontram os cibermeios do mainstream espanhol do ponto de vista de novas formas de participação e, mais concretamente, analisamos weblogs referenciais assinados por jornalistas e/ou convidados, a fim de determinar o perfil desses autores. Um questionário respondido por $50 \%$ destes bloggers nos permite saber por que o uso de weblogs representa a chave para o sucesso da mídia na esfera on-line. Durante o ano de 2008, foram analisados vários websites de jornais, tanto nacionais (Abc.es, Elmundo. es, Elpais.es) como regionais (Elcorreodigital.com, Lavanguardia.es) e, entre eles, salientamos o caso especial do grupo Vocento, um dos principais grupos multimídia da Espanha. Nossos resultados mostram que a oferta de weblogs em circulação é uma boa estratégia contra a crise: os cibermeios obtêm uma quantidade significativa de conteúdo on-line automaticamente e sem nenhum investimento necessário. Isso ajuda a aumentar o tráfego do site, prolonga o tempo gasto pelos visitantes, e colabora para que esses cibermeios consigam melhor posicionamento nos motores de busca da web. Palavras-chave: Internet. Cibermeios. Weblog. Jornalista. Espanha. 


\section{INTRODUCTION}

The Internet media scene has suffered important transformations from its beginning. One of the most recent examples is the integration of web 2.0 tools in the online media, and the intensive use of participatory journalism.

According to recent reports, there are more than 23 millions Internet users of ages of 15 and above in Spain and 45,7\% are women (ESTUDIO GENERAL DE MEDIOS, 2012). 77\% Spanish population who accessed the Internet from home or work computers visit social networking sites (NIELSEN, 2010). Compared to other countries with Internet populations of at least 10 million monthly unique visitors, Spain had the third highest relative penetration in the social networking category, behind Brazil (86\%) and Italy (78\%) (UREÑA, 2011). The Social Media Research developed by Universal Mccann shows that, in Spain, these activities are focused on weblog reading (78\%), picture sharing (46\%) and video uploads (30\%).

This panorama justifies that most of Spanish radio, television and newspaper websites encourage audience participation in news production everyday. These online media have developed specific sections called "Participation" to group all the possibilities: sharing of news, posts, photos and video; voting and correction of contents; creating weblogs; participating in creative contests... A content analysis could show the interest existing in increasing the interaction with the audience and providing the latter with a more significant role.

Ease of use has permitted an indiscriminate creation of blogs in all sectors, with the journalist guild being one of the most active and committed to regular updating. In 2005 we detected only two hundred journalist-blogs (j-blogs) in Spain (PALOMO, 2005); one year later that number was multiplied by three (PALOMO, 2007). At the same time, journalist-blogs have also got a remarkable place in online media home pages, but this phenomenon has been scarcely investigated. During 2008, we analyzed this situation using several national, regional and local internet newspapers, as members of a national research project.

\section{State of the Question}

The novelty of the concept of "participatory journalism" (DOMINGO et al., 2007) is an invitation for the constant discovery of new research possibilities in the subject. The United States is the country where the greatest volume of studies has been developed on participatory journalism, also known as citizen journalism (MESO, 2005), 
3.0 journalism and open code journalism. The We Media report, drawn up by Chris Willis and Shayne Bowman (2003), has become established as an international referent on this subject. Similarly, this form of journalistic practice, which includes participation by the public, is attracting the attention of different researchers from around the world, including Mark Deuze (2008) and Stephen D. Reese, Lou Rutigliano, Kideuk Hyun and Jaekwan Jeong (2007). The Pew Internet Center has promoted some of the best known studies on the profile of the creators and/or readers of blogs, based on surveys; Technorati makes available annual reports that reflect the state of the blogosphere based on the data of its weblog search-engine. The latter case involves a quantitative vision that makes a census of blogs, establishes the seasonal character of the creations, the volume of daily entries and the predominant languages, making it possible to trace tendencies and observe their evolution over time.

Empirical research in citizen journalism was at an early stage in 2008, and the methodological approaches vary greatly, seeking the most suitable perspective for dealing with the phenomenon. These perspectives include: structural analysis of the opportunities for participation offered by the websites of conventional media; content analysis of the "journalistic" material produced by citizens; and interviews with journalists, promoters of citizens' media and citizens themselves, in order to understand their attitudes and motivations. From the conceptual point of view, a specific terminology has also emerged, which has favoured semantic approaches and reflection on the indiscriminate creation of new words (SCOLARI; PARDO, 2006).

Citizen journalism includes any form of participation by the audience linked to current news (HERMIDA; THURMAN, 2008). Many of the innovations in this area do not proceed directly from journalism, but from Web 2.0 services, such as Wikipedia, YouTube, Flickr, etc. As objects of study, blogs and their relation to journalism have attracted most of the scientific work in this field, although more recently attention has shifted towards other participatory tools.

Most stories about citizen journalism and blogs in the U.S. tend to focus on sites written in English (CARL, 2003; LOWREY, 2006). Because of this, we decided to approach the Spanish case through this paper. The blog phenomenon is being monitored and characterized by Spanish researchers from three different perspectives: the profile of bloggers, the relation between blogs and journalism, and journalists as bloggers. Online questionnaires (open surveys and closed models) have provided most of the data. The most documented and relevant 
academic studies on the situation of the Spanish blogosphere have been the collective works Do We Live in a Small World? Measuring the Spanish-speaking Blogosphere (TRICAS et al., 2003) and Revisiting the Spanish Blogosphere (MERELO et al., 2004).

\section{An approach to the Spanish scenario}

The first Spanish cybermedia census was created in 2005. The national research project "El impacto de Internet y los medios de comunicación en España" ("Internet impact and mass media in Spain"), funded by the Department of Science and Technology, detected 1.250 online media (SALAVERRÍA, 2005). Some of them have got international awards thanks to their contents and/or design (SND, Malofiej).

Despite that huge number, most high-profile citizen media sites in Spanish are from newspapers. In 2006 Elmundo.es had a collaborative weblog under the title "Ciudadano M - Tú haces las noticias". People living in or visiting Madrid contributed and it became noticeably famous because several scoops appeared in it. Elpais.es launched in 2007 a citizen journalism section, Yo, Periodista, where readers are turned into journalists, because they create all the contents. At the end of the same year, Soitu.es was born; a self-funded independent project, developed by Gumersindo Lafuente, Elmundo.es ex-editor, who pays 20 euros to every news story appearing in the home page. In general, national television stations and radios limit user participation to comments, chats or forums. On this context, we should note also the lack of a specific proposals for "wiki journalism".

\section{Vocento: The First Case Study}

In 2008, we decided to analyze the special case of Vocento, one of the main multimedia groups in Spain. An exploratory content analysis of the 13 Vocento's online newspapers revealed that many provide interactive options (PALOMO; MESO, 2009).

Vocento's online dailies redefined their functions in the Internet in 2007, incorporating a new section called "Participation", where the audience becomes the main emitter. While the media of other groups limited the action of the reader to voting the news, to correcting them or to sending stories to some friends or colleagues, the 13 Vocento's cyberdiaries have incorporated tools that have increased the role of users in the configuration of their contents, allowing them to create their own weblogs, to comment the news, to vote in surveys, to send complaints, videos and their own news. 
We also chose this company because it pioneered participative journalism in 2005 by starting to offer free of charge services to let users create their own weblog. Sur.es, one of its 13 online local newspapers, was hosting more than six hundreds blogs generated by users at the beginning of 2008 .

\section{A new loyalty}

These innovations have increased the loyalty to the new medium. After checking audience data in every online cyberdaily, we detected that media with less intensive use of web 2.0 tools had poorer traffic results and shorter visits. According to Spanish control of circulation office (OJD), the users spent 4 minutes and 24 seconds visiting Spanish in 2008. In the case of Vocento's Internet newspapers, the time rises to 11 minutes and 37 seconds.

At the same time this media organization increased its interactive efforts, it invented more innovative features (CHUNG, 2007). For example, newspapers are publishing relevant comments of forum discussions in their print editions, and encourage stories written by journalists in close cooperation with readers. We can present several examples. On the occasion of the birthday of actress Marisol, one reader made a proposal in Sur.es: the town hall of Malaga should make her a present, a monument. This opinion received hundreds of comments supporting the idea, and finally the major has applied this suggestion. The same Internet newspaper received in 2007 more than 18.000 user pictures, and art editors chose to make a public exhibition in a gallery of Malaga.

Another reason to select Vocento's media was that we observed a huge increase in the number of offered journalist-blogs. While the multimedia group hosted only 30 j-blogs in 2005, three years later this number soared to 176 .

\section{Methodology}

The survey is the most widespread resource for rapidly obtaining information on the maintenance of the weblog and the author's profile. After searching the Vocento's newspapers websites and locating the 176 outstanding blogs that are the object of study, a universe was built to which the survey with fifty items was then sent by electronic mail in *.doc format together with a link to an online version of the questionnaire available during February and March 2008, so the respondents could fill in the form in the way they preferred. Companies like 2ask, QuestionPro, 
e-encuesta or Netquest facilitate the design of these questionnaires and provide the results automatically, which expedites data gathering and analysing. In this case, different studies centered on the figure of the news professional (PALOMO, 2007) have employed this method, as it is considered to be the most suitable for tracing the profile of the blogosphere elaborated by journalists (BLOOM, 2003).

94 answers were received, which were part of a simple random sample, i.e. all members of the population have the same chance of being chosen.

Besides the survey, we interviewed experts like multimedia coordinators as another method for directly determining how citizen journalism is influencing journalistic routines, since in this way professionals can confirm the use of tools like Flickr or Buzznet. Authors like Jane Singer (2005) opted for content analysis in order to compare the style and values of journalist-bloggers with "standard" news.

\section{The j-blogger profile}

The prototype of outstanding blogger in Vocento's Internet media is a man graduated in Journalism (50\%), with more than fifteen years of professional experience $(47,1 \%)$ and a permanent job in the multimedia group (53,8\%), and from the point of view of the blogosphere, a self-taught person.

Only $34,4 \%$ of j-bloggers show their e-mail address, whereas $36,6 \%$ prefer not to because they don't have enough time to answer messages (52,9\%), they worry about spamming or receiving virus $(29,4 \%)$, or because they prefer to respect the essence of blogosphere receiving comments only in a public way. Half of these bloggers disagree with offering their personal profile too.

Most of these authors are male (83\%) and $72 \%$ of those polled are between 26 and 45 years old. Only 22,2\% work in several mass media, and $10,6 \%$ of those polled are guests collaborating with the online edition. Life $(15,6 \%)$ and Local $(13,1 \%)$ sections journalists show the highest levels of compromise with the creation of weblogs.

The offer of topics is very wide, although journalists try to avoid controversial subjects. They are in favour of a relaxed way of journalism, using alternative point of views, or writing about topics in which they are personally interested (hobbies, sports, travelling...). In fact, only 51,8\% of those polled write about the same subjects on their weblog and in their mass media. One of every five blogs is miscellaneous, with a great variety of contents. Weblogs specialized in culture (14,9\%) and sports 
$(12,8 \%)$ are the second and third most frequent categories, respectively.

\section{Blogging as a journalistic task}

Most of these journalists (71\%) consider maintaining a weblog as a journalist task, because they apply the same requirements: accuracy, simplicity and objectivity. In fact, most of them (84\%) believe the contents in their weblogs are as credible as the contents they produce in traditional mass media. At the same time, $70 \%$ of journalists polled consider their role similar to that of the columnist.

Nearly $40 \%$ of these authors feel this task as an entertainment, and $19,2 \%$ think it is a social work. Others view it as a way of life, a showroom or an option to escape of the alienating routines.

Half of j-bloggers polled confirm that the editor in chief gave them the assignment of creating a weblog, whereas in $39,2 \%$ of the cases it was an individual initiative. Despite this company interest, only $21,5 \%$ have received specific training to learn to use these new tools. Eight of every ten journalists polled admit that they are self-taught in the blogosphere context.

\section{Why do they blog?}

The interaction between journalists and the public and its rules resulted to be another interesting subject. They feel free to blog about anything. In fact, in $92,1 \%$ of cases they stated that they were certain that their companies had not developed any rules to apply in weblogs. The only company advice is not to be rude or disrespectful to somebody.

Nearly $6 \%$ of these bloggers have asked for permission to open other weblogs outside the Internet newspaper. But probably the most interesting result is that none of these j-bloggers is receiving any money for carrying out this activity. They are creating more contents for free. So, why do they do it? Which kind of motivation do they have? Nearly $6 \%$ have a weblog because it is an opportunity to write about topics they really like; $12,8 \%$ use their weblogs to search for sources; $10,6 \%$ get news stories, and the rest has very different motivators: they do it just for the fun of it; for personal and professional satisfaction; or as a showcase to promote their contents; or to have influence and getting prestige. One blogger out of every ten polled has received job offers through their weblogs.

Most of the time they insert posts at home $(68,1 \%)$. Despite $48,9 \%$ update contents at newsrooms, they cannot reduce the time devoted to their professional routines. Having a blog is considered an 
extra task, and because of this they cannot spend more than 30 minutes in writing each post (43,35\%).

Based on their experience, some of the consequences of blogging are: to have a fresher writing style (50\%); to be able to talk to the audience (50\%); to learn from the audience $(36,2 \%)$; to go deeper into news stories $(36,2 \%)$ thus avoiding a superficial approach; to avoid editorial pressure $(26,6 \%)$; to be more popular $(14,9 \%)$, to write about topics forbidden by their companies $(7,5 \%)$ or to be capable of writing about mere rumours $(4,3 \%)$. We have to add one more item: thanks to weblogs, retired journalists keep working.

These j-bloggers feel closer to audience, but 36,2\% don't know which differences exist between the readers of their blogs and the ones of the traditional newspapers. $27,7 \%$ of them believe that their blog reader is younger and demanding (19,2\%). Finally, the impact of their blog contents in public opinion is unknown by $45,7 \%$, because $59,1 \%$ never receive any report about the number of visits. Only $14,9 \%$ of polled bloggers believe that their weblogs have a high influence on society.

Anyway, one third say that their weblogs are more successful than they thought. Only 5,3\% consider that their blog is a "complete disaster".

Self-criticism has been too part of the study. The weak points of these weblogs, as considered by their own authors, are: irregular updating $(46,8 \%)$, poor website design (30,9\%) and develop excessively specific lines (9,6\%). The remaining complaints are about management, complex access, inflexibility of templates and, finally, they miss visit counters.

\section{Risky business}

Sometimes people abuse the freedom of speech. $56,4 \%$ of those polled have received offensive comments, and other users take advantage of this anonymous system to threaten journalists (16\%). When confronted to this kind of situations, bloggers reportedly have taken different approaches. Most authors show absolute respect to freedom of speech (50,9\%); $47,2 \%$ prefer to ignore these comments; $25 \%$ choose to erase disrespectful messages and 9,4\% have considered close the weblog at some point of time.

From the perspective of contents, $63,4 \%$ are not interested on copyright issues. However, $29 \%$ know that people sometimes illegally copy their posts, and mass media make reference to their texts $(36,6 \%)$.

It was very interesting to analyze their attitude towards new technologies, to check if there was a great influence of their companies on their weblog activity or if they were moved by personal interest. In 
this sense, $63,4 \%$ of $\mathrm{j}$-bloggers are active writing comments in several weblogs. Only $39,8 \%$ are subscribed to weblogs.

\section{Technological attitude}

News about the Internet and new technologies are very important for them $(93,6 \%)$. Some of them have a personal website $(19,2 \%)$, weblogs out of Vocento (25\%), photoblog (10,6\%) and videoblog $(1,32 \%) .6,4 \%$ have updated their weblog using the cellular phone in some occasion. In most of their weblogs text prevails over multimedia formats, although 64,9\% do apply pictures, audio and/or video.

They are in favour of citizen journalism (70\%), and most of them believe it is not dangerous for the journalistic profession.

We decided to propose them an exam at the end of the questionnaire, in order to assess their knowledge about social web tools. Youtube was the only one identified by all of them, following Wikipedia (98,9\%), Second Life $(81,1 \%)$, RSS (54,4\%), Twitter (33\%), blogroll, Digg and Delicious (24\%).

\section{The mainstream media pattern}

After this experience, during the last months of 2008 we decided to extend the study to five mainstream online media, focused on five case studies: three national newspapers (Abc.es, Elmundo.es, Elpais.es) and two powerful regional newspapers (Elcorreodigital.com and Lavanguardia.es).

Recently, dozens of Internet newspapers and mainstream media in general have deployed correspondent weblogs in their websites and have introduced sections where Spanish citizens living in other countries can write about their experiences in a public way having a global connection.

\section{Similar results}

In total, we analyzed 202 weblogs, being Lavanguardia.es the one with the bigger offer (66), followed by Elmundo.es (58), El pais. es (31), Abc.es (28) and Elcorreodigital.com (19). Applying the same methodology and tools, results have been significantly similar to Vocento's investigation. Most demographic questions and opinions described in previous paragraphs are shared by these outstanding Internet newspapers bloggers. That is why we are going to discuss only the differences.

The first one we found is that $40 \%$ are just collaborators with the medium, while $32 \%$ have a full-time job and $28 \%$ work as correspondents. 
The last percentage justifies that the best represented section in national newspaper blogs is international affairs.

Most of these bloggers don't receive any income because of this activity, but the percentage of paid weblogs (30\%) is much higher than in regional and local cybermedia, represented by Vocento. Probably related with this item, their compromise with internet newspaper weblogs is higher too. Looking for a quality production, 68\% of those polled spend more than 30 minutes working on their posts, and they try to add contents more often. $42 \%$ of outstanding bloggers write posts several times per week, and only $5 \%$ consider blogging a daily task. These bloggers are more exposed to offensive comments $(66 \%$ have received rude messages).

National newspapers have a great echo in society. In fact, 39\% of those polled know that people have reproduced their posts, and mass media make reference to their texts (51\%).

From the formal point of view, the structure of blogs in Spanish mainstream cybermedia is very similar, as they normally respect the template provided by the web where they are housed or they make only small modifications, which is why graphic creativity is almost nonexistent, with the result that their visual elements attract little research interest. Despite this context, $53 \%$ of studied bloggers add multimedia contents, and the number rises to $88 \%$ in picture usage.

Finally we asked for their favourites j-blogs. Regarding international blogs, it was considered that the best ones are written by Greg Howson, Nick Robinson, David Alan Harvey and many hosted by The New York Times, The Inquirer, Time, or the well-known Drudgereport, Sluggerotoole.com and The Huffington Post. In Spain, Periodistas 21 received most of the votes.

\section{Conclusions}

Spanish journalistic websites are exploiting the opportunities offered by the new medium. By offering outstanding weblogs, media obtain a significant amount of online content automatically and with no investment needed. From the point of view of business, this helps to increase the website traffic, to lengthen the time spent by visitors; and to obtain a better place in web search engines. Since the number of visits is the main indicator used by media when negotiating advertising fares, it can be concluded that in the case of Vocento, as well as for other media groups in which blogs have been deployed, these are used to leverage higher audiences and therefore increase 
their advertising income. Founding or updating weblogs implies no extra cost for the local, regional or national mass media company, and media get an extra echo in society.

From the point of view of bloggers, six out of every ten notable bloggers are maintaining a weblog because it is the only way to talk about the topics he or she is really interested on. The attitudes towards the new media of many Spanish journalists are anything except reticent or skeptical. Notable journalists share their free time writing for the Internet users, and they are very generous because they normally don't receive any money with this activity. Only some national newspapers are paying bloggers, and they practice a kind of discrimination, because they don't pay to all their bloggers. This situation shows that digital journalism is still underestimated by mass media companies.

In general, we can conclude that journalists are preparing themselves for an age of participatory news, adquiring a new active role in the process of generating more contents for an informal context.

Finally, collaborative blogs were not very extended in 2008 (18\%), but there was great potential to grow and a lot of enthusiasm around these projects.

\section{REFERENCES}

BLOOM, Joel David. The blogosphere. How the Once Humble Medium Came to Drive Elite Media Discourse and Influence Public Policy and Elections. Trabalho apresentado ao 2 Annual Pre-APSA Conference on Political Communication, Conference on Mass Communication and Civil Engagement, Georgetown, 2003.

CARL, Christine. Bloggers and Their Blogs: A Description of the Users and Usage of Weblogs on the World Wide Web. Thesis. Washington DC: Georgetown University, 2003.

CHUNG, Deborah. Profits and Perils: Online News Producers' Perceptions of Interactivity and Uses of Interactive Features. Convergence, vol. 13, n. 1, p. 43-61, 2007.

DEUZE, Mark. Understanding Journalism as Newswork: How it Changes, and How It Remains the Same. Communication and Culture, vol. 5, n. 2, p. 4-23, 2008.

DOMINGO, David; QUANDT, Thorsten; HEINONEN, Ari; PAULUSSEN, Steve; SINGER, Jane; VUJNOVIC, Marina. Participatory journalism practices in the media and beyond: an international comparative study of initiatives in online newspapers". Work presented at Conference The Future of Newspapers, Cardiff, Wales, p. 326-342, 2007.

ESTUDIO GENERAL DE MEDIOS. Audiencia de Internet (febrero/marzo 
2012). Available at: <http://www.aimc.es/-Audiencia-de-Internet-en-elEGM-.html>. Accessed: 31 July 2012.

HERMIDA, Alfred; THURMAN, Neil. A clash of cultures: The integration of user-generated content within professional journalistic frameworks. Journalism Practice, vol. 2, n. 3, p. 343-356, 2008.

LOWREY, Wilson. Mapping the journalism-blogging relationship. Journalism, vol. 7, n. 4, p. 477-500, 2006.

MERELO, Juan J.; ORIHUELA, José Luis; RUIZ, Víctor; TRICAS, Fernando. Revisiting the Spanish Blogosphere. In BURG, Thomas N. (ed.). BlogTalks 2.0. The European Conference on Weblogs. Viena: Donau-Universität Krems Kulturwiss, p. 339-352, 2004.

MESO, Koldobika. Periodismo ciudadano: voces paralelas a la profesión periodística. Chasqui. Revista Latinoamericana de Comunicación, 90, p. 4-13, 2005.

NIELSEN. Cómo mira la gente. 2010. Available at: <http://es.nielsen. com/news/documents/Reporte-Comomiralagente_Agosto2010.pdf>. Accessed: 31 July 2012.

PALOMO, Bella. Periodistas en la red. Informe Anual de la Profesión Periodística 2005. Madrid: Asociación de la Prensa de Madrid. p. 309319, 2005.

Blogs en el espacio iberoamericano. Medios de Comunicación - Tendencias 2007. El escenario iberoamericano. Madrid: Fundación Telefónica y Ariel, 2007. p. 215-225.

PALOMO, Bella; MESO, Koldobika. Perfil y comportamiento de los autores de los blogs destacados en los ciberdiarios de Vocento. Anàlisi, 38, p. 99-116, 2009.

REESE, Stephen; RUTIGLIANO, Lou; JUN, Kideuk; JEONG, Jaekwan. Mapping the blogosphere: Citizen-based media in the global news arena. Journalism: Theory, Practice, Criticism, vol. 8, n. 3, p. 235-262, 2007.

SALAVERRÍA, Ramón. Cibermedios. El impacto de internet en los medios de comunicación en España. Sevilla: Comunicación Social, 2005.

SCOLARI, Carlos; PARDO, Hugo. Web 2.0. caso conceptual y nuevos mitos en el discurso cibercultural. Paper presented to IX Congreso Ibercom-El Espacio Iberoamericano de Comunicación en la Era Digital. University of Seville. Available at: <http://alojamientos.us.es/cibercom/ pdf/ScolariCarlos.pdf>. Accessed: 7 July 2011.

SINGER, Jane B. The political j-blogger. 'Normalizing' a new media form to fit old norms and practices. Journalism, vol. 6, n. 2, p. 173-198, 2005.

TRICAS, Fernando; RUIZ, Victor; MERELO, Juan J. Do we live in a small World? Measuring the Spanish-speaking Blogosphere,. In BURG, Thomas. N. (ed.). BlogTalks: First European Conference on Weblogs. Viena: Zentrum für Wissenschaftliche Forschung und Dienstleistung, Vienna, 2003, pp. 158-172.

UREÑA, A. (coord.). Las redes sociales en internet. Observatorio Nacional 


\section{de las Telecomunicaciones y de la Sociedad de la Información, diciembre, 2011.}

WILLIS, Chris.; BOWMAN, Shayne. We Media. How audiences are shaping the future of news and information. Reston: The Media Center at the American Press Institute, 2003.

\section{Acknowledgements}

This work is part of the national research project "Evolución de los cibermedios españoles en el marco de la convergencia" (Evolution of Spanish Cybermedia in the Context of Convergence) with the reference number CSO2009-13713-C05-04, supported by the Department of Science and Technologya.

\section{Koldobika Meso Ayerdi is a Doctor in Communication and a lecturer} in journalism in the Faculty of Social and Communication Sciences of the University of the Basque Country (UPV-EHU) in Spain, where he teaches subjects related to media models and online journalism. He was also Director of the Digital Journalism Course of Asmoz Fundation, and member of Spanish national research projects about this topic. His main research fields are new technologies, cyberjournalism and the web 2.0. E-mail: koldo.meso@ehu.e

Maria Bella Palomo Torres is professor at the University of Malaga, Spain. Palomo has focused her line of research on digital journalism. Author of The online journalist: from revolution to evolution (2004), she has written articles about cybermedia's design; the relationship between the Internet and the journalists, and, more recently, the web 2.0. Member of Spanish national research projects about these topics during the last decade, she has been visiting scholar at the University of Washington, Rutgers (US) and Universidade Federal de Bahia (Brazil). E-mail: bellapalomo@uma.es 